\title{
KARAKTERISTIK MEKANIK PRODUK FIBERBOARD DARI KOMPOSIT SAMPAH PLASTIK (THERMOPLASTIC)-LIMBAH TANDAN KOSONG KELAPA SAWIT (TKKS)
}

\author{
Feris Firdaus dan Fajriyanto \\ Pusat Penelitian Sains dan Teknologi, Direktorat Penelitian dan Pengabdian Masyarakat, \\ Universitas Islam Indonesia, Jalan Kaliurang Km.14,5 Sleman, Jogjakarta \\ Telp. (0274) 896447 ext. 2503 Faks. (0274) 896448 ext. 2504 \\ HP. 08170436061 E-mail : fiva_izause@yahoo.com \\ (Riset ini adalah Bagian dari Riset Unggulan Terpadu / RUT XII yang dibiayai oleh \\ Menristek RI pada tahun 2005-2006)
}

\begin{abstract}
The research about thermoplastic wastes-oil palm fiber wastes composites have been conducted. Thermoplastic wastes has become a serious problem in Indonesia, and oil palm fiber wastes also become a serious problems in palm oil industries. The quantity and abundance of the wastes are very much but their utilization is not optimal yet even has no significant added, economic values. The research was to utilize thermoplastic wastes and oil palm fiber wastes as the main materials to produce fiberboards. The research yields showed that thermoplastic wastes and oil palm fiber wastes composites could be used to produce fiberboards with very satisfied mechanical properties. The mechanical properties of the product were very satisfied even competitive to similar products in markets. The mechanical properties of fiberboards recommended for many kind of materials application, like in building materials and exterior-interior accessories in many appropriate places. Keywords: thermoplastic waste, oil palm fiber waste, composite, fiberboard
\end{abstract}

\section{PENDAHULUAN}

Kelapa sawit adalah salah satu komoditi andalan Indonesia yang perkembangannya demikian pesat. Selain produksi minyak kelapa sawit yang tinggi, produk samping atau limbah pabrik kelapa sawit juga tinggi, limbah padat yang berasal dari proses pengolahan berupa Tandan Kosong Kelapa Sawit (TKKS), cangkang atau tempurung, serabut atau serat, sludge atau lumpur, dan bungkil [1]. Setiap tahun di Indonesia sekitar 5 juta ton limbah biomasa (dalam bentuk Tandan Kosong Kelapa Sawit/TKKS) dihasilkan dari pabrik kelapa sawit [2]. Di Indonesia, hingga akhir 2003, penggunaan bahan plastik diperkirakan akan mencapai 2 juta ton, sehingga potensi limbahnya diperkirakan 1,6 juta ton atau 80 persen [3].

Perkembangan teknologi, khususnya di bidang komposit, telah menghasilkan produk komposit yang merupakan gabungan antara serbuk kayu dengan plastik daur ulang dan teknologi ini berkembang pada awal 1990-an di Jepang dan Amerika Serikat. Berbagai penelitian terdahulu telah berhasil membuat komposit dari kayu dan plastik polipropilen murni dan daur ulang dengan 
campuran bahan kimia sebagai compatibilizer/coupling agent, beberapa penelitian tersebut pernah dilakukan oleh peneliti-peneliti sebelumnya. Di Indonesia penelitian tentang produk komposit tersebut masih sangat terbatas, padahal bahan baku yang berupa limbah kelapa sawit dan sampah plastik di alam potensinya sangat besar, dan belum termanfaatkan secara optimal bahkan menjadi problematika serius bagi bangsa Indonesia.

Ultra struktur kimia maupun fisik dari kayu dan TKKS secara kualitas tidak jauh berbeda, komposisi kimianya adalah lignoselulosa (serat) yang berisi selulosa, hemiselulosa, lignin dan sedikit senyawa anorganik/abu, yang agak berbeda adalah komposisinya secara kuantitatif. Hal demikian telah menantang Penulis untuk menggali dan memanfaatkan potensi TKKS yang dikompositkan dengan sampah plastik. Dalam hal ini TKKS berfungsi sebagai filler sedangkan sampah plastik sebagai matriks yang didukung dengan compatibilizer/coupling agent, proses pembuatanya dilakukan secara polimerisasi. Dengan merekayasa/modifikasi kerangka teknologi yang telah dilakukan oleh beberapa peneliti tersebut, dimungkinkan pemanfaatan limbah kelapa sawit (TKKS) dan sampah plastik yang melimpah di alam secara optimal, dengan demikian akan menekan volume sampah atau limbah yang dihasilkan oleh kegiatan industri dan lingkungan hidup.

Pembangunan perumahan khususnya tipe rumah sederhana (RS) dan rumah sangat sederhana (RSS) yang ditargetkan pemerintah tidak pernah terpenuhi, hal itu diakibatkan oleh banyak faktor, tetapi faktor utamanya adalah minimnya kesediaan bahan bangunan sehingga harga penjualannya tidak terjangkau oleh masyarakat umum. Untuk memenuhi target tersebut tentu dibutuhkan teknologi bahan alternatif khususnya untuk menyediakan penyediaan panel bangunan yang lebih ekonomis dan efisien ruang.

Oleh sebab itu penelitian ini sangat penting untuk dilakukan karena dirancang untuk memberdayakan potensi limbah kelapa sawit (TKKS) dan sampah plastik yang melimpah dan menjadi problem lingkungan secara nasional untuk dimanfaatkan sebagai bahan baku pembuatan komposit panel bangunan yang diharapkan dapat menggantikan peranan kayu yang mulai terbatas sediaannya, bahkan dapat pula menggantikan peranan beton/semen yang tidak ekonomis dan inefficien. Produk penelitian ini berupa komposit yang merupakan perpaduan dari TKKS dan sampah plastik yang dapat digunakan sebagai papan meja, kursi, jendela, pintu, tabir, plafond dan perabot yang lain, bahkan sebagai dinding interior tipis dan kuat yang dapat mengganti penggunaan dinding interior dari beton (semen-bata) yang terlalu tebal sehingga menyebabkan inefficiency ruang. Harapan dari terealisasinya penelitian ini adalah dapat ditumbuhkembangkan industri panel bangunan yang dapat meningkatkan persediaan bahan bangunan perumahan yang ekonomis/terjangkau oleh masyarakat Indonesia secara luas dengan memanfaatkan sepenuhnya local resources yang tentu ramah lingkungan.

Penelitian dan pengujian komposit kayu plastik sampai sejauh ini masih dalam bentuk lembaran tipis, sehingga pengujiannya masih mengacu pada pengujian plastik. Untuk ke depan perlu diadakan penelitian tentang bagaimana 
membuat komposit kayu plastik daur ulang dalam bentuk small clear specimen sehingga pengujian diarahkan kepada kemungkinan penggunaan komposit sebagai pengganti kayu dan panel bangunan dari beton. Penelitian selanjutnya akan mengarah pada penentuan proses pembuatan papan komposit dari plastik dan bahan berlignoselulosa tinggi yang terbaik dan sederhana serta mudah diaplikasikan serta peningkatan mutu papan komposit melalui perlakuan pendahuluan pada filler, pemilihan modifier/compatibilizer, inisiator, penentuan variabel-variabel proses, maupun pemanfaatan bahan-bahan berlignoselulosa selain kayu, misalnya limbah padat kelapa sawit yang berupa tandan kosong kelapa sawit (TKKS) yang ternyata banyak mengandung lignoselulosa tinggi. Jadi jelas bahwa penelitian ini merupakan penelitian lanjutan dari penelitian sebelumnya yang lebih komprehensif dengan rekayasa dan modifikasi sederhana untuk memudahkan dalam aplikasinya pada tingkat praktis.

\section{Keadaan Transien}

Metodologi penelitiannya menggunakan design penelitian eksperimen murni (true experimental research). Tahapan penelitiannya dibagi menjadi tiga yang dimulai dengan preparasi dan sampling bahan baku, compatibilizer/coupling agent dan alat produksi. Tahapan berikutnya adalah proses pembuatan komposit sampah plastik-limbah tandan kosong kelapa sawit yang dimulai dengan proses blending dan pembentukan serta pencetakan komposit menjadi papan/panel bangunan (fiberboards). Tahapan terakhir adalah pengujian karakteristik mekaniknya (bending) produk yang dihasilkan. Metode alternatif yang digunakan merupakan rekayasa/modifikasi dan penyederhanaan dari metode pembuatan komposit kayu-polipropilen dan kayu-resin ureaformaldehida yang sudah pernah dilakukan oleh peneliti sebelumnya [4], [5], [6], [7], [8], [9], [10], [11], [12].

Bahan baku TKKS yang masih basah dijemur kemudian di oven dalam suhu 50 oC untuk mempercepat proses pengeringan. Setelah kering, TKKS diurai menjadi serat kemudian dipotong kecil-kecil dengan ukuran 1-1,5 cm. Setelah itu dilakukan penggilingan dengan alat sehingga menjadi lembut dan dilanjutkan dengan penyaringan ukuran 50 mesh. Bahan baku TKKS yang telah mencapai ukuran 30, 50, 70 mesh merupakan filler yang siap untuk dilakukan proses berikutnya. Persiapan bahan baku berupa sampah plastik (thermoplstic) diperoleh dari tempat sampah di TPA di Sidoarum Godean Sleman. Sampah plastik polypropilena dicuci sampai bersih kemudian dikeringkan dengan cara dijemur. Sampah plastik (thermoplastic) yang sudah kering dipotong-potong untuk kemudian dipanaskan sampai titik lelehnya kemudian dicetak hingga berbentuk pellet. Pellet plastik telah siap menjadi bahan baku komposit yang berfungsi sebagai matrik. Compatibilizer/ coupling agent diperoleh dari Laboratorium Kimia Terpadu FMIPA UII.

Alat yang digunakan untuk proses pembuatan produk komposit terdiri dari kompor pemanas, alat untuk proses blending dan casting yang berfungsi untuk pencetak komposit hasil proses blending. Casting dibuat secara khusus untuk memenuhi tujuan penelitian karena peralatan yang ada di laboratorium tidak sesuai untuk penelitian ini. Casting berupa alat pengempa yang dibuat mempunyai 
variasi ukuran pada cetakannya dan dilengkapi dengan presser hidroulik sehingga tekanan saat pencetakan terukur dan dapat dilakukan dengan tekanan 350, 700, 1050, $1400 \mathrm{~kg}$. Alat ini merupakan rekayasa yang dilakukan peneliti sehingga menghasilkan komposit yang berkualitas.

Proses produksi komposit meliputi kegiatan penimbangan berat bahan baku, proses blending dan casting untuk pembentukan komposit. Berat bahan baku berupa pellet plastik dan serbuk TKKS ditentukan sesuai dengan desain penelitian yakni 50:50, 40:60, 30:70 \%. Proses blending dilakukan dengan cara memanarkan pellet plastik sampai suhu $170{ }^{\circ} \mathrm{C}$, kemudian ditambahkan gliserol, setelah itu di campurkan dengan serbuk TKKS yang sebelumnya telah di panaskan sampai suhu $50{ }^{\circ} \mathrm{C}$. Setelah itu dilakukan pengadukan hingga merata dan kemudian dilakukan pencetakan dalam casting yang telah dipersiapkan dengan tekanan sesuai dengan desain penelitian. Hasil proses casting ini merupakan produk komposit, terlihat cukup menyatu dan mempunyai ikatan yang cukup kuat. Hasil produksi komposit ini merupakan benda uji yang siap untuk dilakukan pengujian karakteristik mekanik (kuat desak, kuat lentur, kuat geser dan kuat tarik).

\section{HASIL DAN PEMBAHASAN}

Hasil proses casting yang sudah dilakukan merupakan produk komposit berupa fiberboard, terlihat cukup menyatu dan mempunyai ikatan yang cukup kuat. Hasil produksi komposit ini merupakan benda uji yang siap untuk dilakukan pengujian karakteristik mekanik, lihat gambar 1.
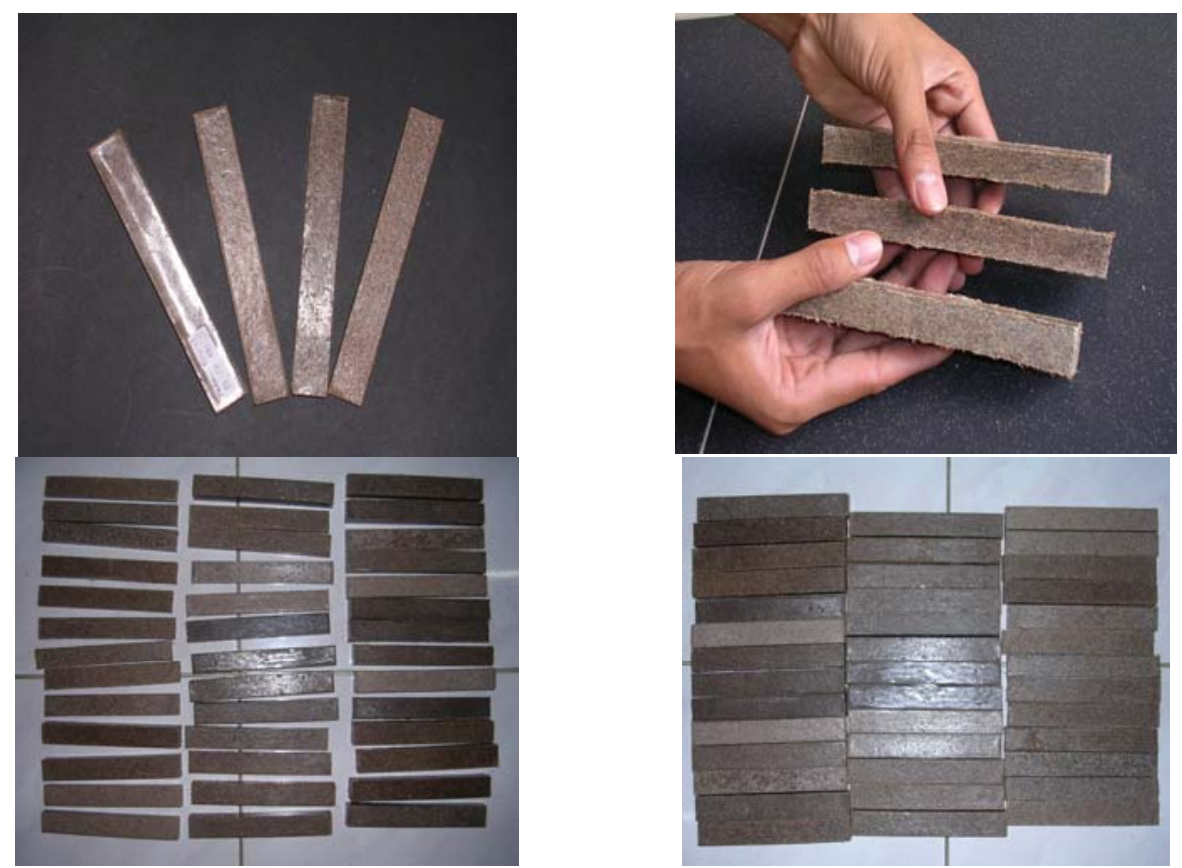

Gambar 1. Produk fiberboard bangunan yang dihasilkan 
Produk fiberboard yang tampak dalam gambar 1 tersebut adalah contoh produk yang dihasilkan untuk diproses selanjutnya yakni pengujian dan analisis karakteristik mekaniknya (kuat desak, lentur, geser, tarik). Proses pembuatan/produksi fiberboard untuk bahan uji telah dilakukan. Proses pembuatan bahan uji ini diperlukan untuk proses pengujian karakteristik mekanik yang meliputi uji kuat desak, lentur, geser dan tarik. Hasil penelitian menunjukkan bahwa TKKS dan sampah plastik dapat dijadikan komposit sebagai panel/papan serat (fiberboards). Untuk mengetahui secara empiris karaktreistik mekanik yang dimiliki produk fiberboard yang dihasilkan maka berikut ini disajikan hasil uji karakteristik mekanik berdasarkan variasi dalam rancangan penelitian.

\subsection{Karakteristik Mekanik Produk Fiberboard yang Dihasilkan}

\subsubsection{Variasi tekanan/beban pengempaan (molding)}

Variasi ini memiliki arti yang sangat penting untuk dilakukan dalam rangka mencari/mengetahui tekanan/beban optimal yang diperlukan untuk memproduksi komposit papan dan dinding interior dengan kualitas paling optimal. Dalam Tabel 1, 2, 3 dan 4 dapat diamati bahwa perlakuan/variasi tekanan/beban pengempaan berpengaruh positif terhadap karakteristik mekanik produk yang dihasilkan. Karakteristik mekanik yang dimaksudkan adalah kuat lentur, kuat desak, kuat geser dan kuat tarik. Dalam penggunaan praktis di pasaran, kuat lentur (bending) menjadi parameter utama dan yang paling penting karena dapat mewakili seluruh karakteristik mekanik produk komposit sehingga parameter lainnya seperti kuat desak, geser dan tarik dapat diabaikan.

Tabel 1. Kuat Lentur/bending berdasarkan variasi tekanan/beban pengempaan

\begin{tabular}{|c|c|c|c|c|c|}
\hline $\begin{array}{c}\text { Tekanan/ } \\
\text { Beban (kg) }\end{array}$ & $\begin{array}{c}\text { Lebar } \\
\text { papan (a) } \\
\mathrm{cm}\end{array}$ & $\begin{array}{c}\text { Tinggi } \\
\text { papan (h) } \\
\mathrm{Cm}\end{array}$ & $\begin{array}{c}\text { Panjang } \\
\text { bentang (L) } \\
\mathrm{cm}\end{array}$ & $\begin{array}{c}\text { Beban } \\
\text { maksimal } \\
\text { P maks }(\mathrm{kg})\end{array}$ & $\begin{array}{c}\text { Kuat Lentur } \\
(\sigma \mathrm{lt}) \\
\left(\mathrm{kg} / \mathrm{cm}^{2}\right)\end{array}$ \\
\hline 350 & 2 & 2 & 10 & 39 & 73,13 \\
\hline 700 & 2 & 2 & 10 & 42 & 78,75 \\
\hline 1050 & 2 & 2 & 10 & 48 & 90,00 \\
\hline 1400 & 2 & 2 & 10 & 56 & 116,25 \\
\hline
\end{tabular}

Berdasarkan hasil analisis regresi linear terhadap variasi tekanan/beban pengempaan dalam kaitannya dengan kuat lentur produk komposit yang dihasilkan seperti yang ditampilkan dalam Tabel 1 tersebut, dapat dikemukakan bahwa variasi tekanan/beban pengempaan tersebut berpengaruh positif terhadap hasil uji kuat lentur produk komposit yang dihasilkan. Diketahui harga r : 0.948 dan $\mathrm{R}^{2}$ : 0,989 dengan taraf signifikansi $5 \%$. Sumbangan variasi tekanan/beban pengempaan tersebut terhadap kuat lentur produk yang dihasilkan adalah 98,9\%. Hasil uji $\mathrm{t}$ sampel tunggal (one-sample $t$ test) terhadap kuat lentur menunjukkan bahwa diketahui $\mathrm{t}$ tabel : 4,303, berdasarkan hasil pengujian diketahui bahwa $\mathrm{t}$ hitung : 9,353 sehingga jelas bahwa t hitung lebih besar dari t tabel (t hitung $>$ 4,303 atau $t$ hitung $<-4,303)$, dari sini dapat diketahui bahwa semakin besar 
tekanan/beban pengempaan maka kuat lentur produk komposit yang dihasilkan semakin besar.

Tabel 2. Kuat Desak berdasarkan variasi tekanan/beban pengempaan

\begin{tabular}{|c|c|c|c|c|c|}
\hline $\begin{array}{c}\text { Tekanan/ } \\
\text { Beban }(\mathrm{kg})\end{array}$ & $\begin{array}{c}\text { Panjang } \\
\text { penampang } \\
\text { (a) cm }\end{array}$ & $\begin{array}{c}\text { Lebar } \\
\text { penampang } \\
(\mathrm{b}) \mathrm{cm}\end{array}$ & $\begin{array}{c}\text { Luas } \\
\text { Penampang } \\
(\mathrm{Ag}) \mathrm{cm}^{2}\end{array}$ & $\begin{array}{c}\text { Beban } \\
\text { maksimal } \\
\text { P maks }(\mathrm{kg})\end{array}$ & $\begin{array}{c}\text { Kuat Desak } \\
(\sigma \mathrm{t}) \\
\left(\mathrm{kg} / \mathrm{cm}^{2}\right)\end{array}$ \\
\hline 350 & 2 & 2 & 4 & 502 & 125,50 \\
\hline 700 & 2 & 2 & 4 & 597 & 149,25 \\
\hline 1050 & 2 & 2 & 4 & 615 & 153,75 \\
\hline 1400 & 2 & 2 & 4 & 658 & 164,50 \\
\hline
\end{tabular}

Berdasarkan hasil analisis regresi linear terhadap variasi tekanan/beban pengempaan dalam kaitannya dengan kuat desak produk komposit yang dihasilkan seperti yang ditampilkan dalam Tabel 2 tersebut, dapat dikemukakan bahwa variasi tekanan/beban pengempaan tersebut berpengaruh positif terhadap hasil uji kuat desak produk komposit yang dihasilkan. Diketahui harga $\mathrm{r}: 0.953$ dan $\mathrm{R}^{2}$ : 0,908 dengan taraf signifikansi $5 \%$. Sumbangan variasi tekanan/beban pengempaan tersebut terhadap kuat desak produk yang dihasilkan adalah 90,8 \%. Hasil uji $\mathrm{t}$ sampel tunggal (one-sample $t$ test) terhadap kuat desak menunjukkan bahwa diketahui $\mathrm{t}$ tabel : 4,303, berdasarkan hasil pengujian diketahui bahwa $\mathrm{t}$ hitung : 18,012 sehingga jelas bahwa $t$ hitung lebih besar dari $t$ tabel ( $t$ hitung $>$ 4,303 atau $\mathrm{t}$ hitung < -4,303), dari sini dapat diketahui bahwa semakin besar tekanan/beban pengempaan maka kuat desak produk komposit yang dihasilkan semakin besar.

Tabel 3. Kuat Geser berdasarkan variasi tekanan/beban pengempaan

\begin{tabular}{|c|c|c|c|c|c|}
\hline $\begin{array}{c}\text { Tekanan/ } \\
\text { Beban }(\mathrm{kg})\end{array}$ & $\begin{array}{c}\text { Panjang (a) } \\
\mathrm{cm}\end{array}$ & $\begin{array}{c}\text { Lebar (b) } \\
\mathrm{cm}\end{array}$ & $\begin{array}{c}\text { Luas } \\
\text { Penampang/ } \\
\mathrm{Ag}\left(\mathrm{cm}^{2}\right)\end{array}$ & $\begin{array}{c}\text { Beban } \\
\text { maksimal } \\
\text { P maks }(\mathrm{kg})\end{array}$ & $\begin{array}{c}\text { Kuat Geser } \\
(\sigma) \\
\left(\mathrm{kg} / \mathrm{cm}^{2}\right)\end{array}$ \\
\hline 350 & 4 & 5 & 20 & 429 & 21,45 \\
\hline 700 & 4 & 5 & 20 & 517 & 25,85 \\
\hline 1050 & 4 & 5 & 20 & 631 & 31,55 \\
\hline 1400 & 4 & 5 & 20 & 790 & 39,50 \\
\hline
\end{tabular}

Berdasarkan hasil analisis regresi linear terhadap variasi tekanan/beban pengempaan dalam kaitannya dengan kuat geser produk komposit yang dihasilkan seperti yang ditampilkan dalam Tabel 3 tersebut, dapat dikemukakan bahwa variasi tekanan/beban pengempaan tersebut berpengaruh positif terhadap hasil uji kuat geser produk komposit yang dihasilkan. Diketahui harga $r$ : 0.991 dan $\mathrm{R}^{2}$ : 0,982 dengan taraf signifikansi $5 \%$. Sumbangan variasi tekanan/beban pengempaan tersebut terhadap kuat geser produk yang dihasilkan adalah 98,2 \%. Hasil uji $\mathrm{t}$ sampel tunggal (one-sample $t$ test) terhadap kuat geser menunjukkan bahwa diketahui $\mathrm{t}$ tabel : 4,303, berdasarkan hasil pengujian diketahui bahwa $\mathrm{t}$ 
hitung : 7,591 sehingga jelas bahwa t hitung lebih besar dari $\mathrm{t}$ tabel (t hitung $>$ 4,303 atau $t$ hitung < -4,303), dari sini dapat diketahui bahwa semakin besar tekanan/beban pengempaan maka kuat geser produk komposit yang dihasilkan semakin besar. Dalam variasi tekanan/beban yang terbatas tersebut diketahui bahwa tekanan/beban pengempaan optimal adalah $1400 \mathrm{~kg}$ dengan perolehan kuat geser sebesar $39,50 \mathrm{~kg} / \mathrm{cm}^{2}$. Berangkat dari pengujian dan analisa tersebut maka tekanan/beban pengempaan optimal yang dapat ditetapkan adalah $1400 \mathrm{~kg}$.

Tabel 4. Kuat Tarik berdasarkan variasi tekanan/beban pengempaan

\begin{tabular}{|c|c|c|c|c|c|}
\hline $\begin{array}{c}\text { Tekanan/ } \\
\text { Beban }(\mathrm{kg})\end{array}$ & $\begin{array}{c}\text { Panjang (a) } \\
\mathrm{cm}\end{array}$ & $\begin{array}{c}\text { Lebar }(\mathrm{b}) \\
\mathrm{cm}\end{array}$ & $\begin{array}{c}\text { Luas } \\
\text { Penampang } \\
(\mathrm{cm} 2)\end{array}$ & $\begin{array}{c}\text { Beban } \\
\text { maksimal } \\
\text { P maks }(\mathrm{kg})\end{array}$ & $\begin{array}{c}\text { Kuat } \\
\text { Tarik }(\sigma) \\
(\mathrm{kg} / \mathrm{cm} 2)\end{array}$ \\
\hline 350 & 2 & 1 & 2 & 30 & 15,00 \\
\hline 700 & 2 & 1 & 2 & 34 & 17,00 \\
\hline 1050 & 2 & 1 & 2 & 51 & 25,50 \\
\hline 1400 & 2 & 1 & 2 & 52 & 26,00 \\
\hline
\end{tabular}

Berdasarkan hasil analisis regresi linear terhadap variasi tekanan/beban pengempaan dalam kaitannya dengan kuat tarik produk komposit yang dihasilkan seperti yang ditampilkan dalam Tabel 4 tersebut, dapat dikemukakan bahwa variasi tekanan/beban pengempaan tersebut berpengaruh positif terhadap hasil uji kuat tarik produk komposit yang dihasilkan. Diketahui harga r : 0.941 dan $\mathrm{R}^{2}$ : 0,886 dengan taraf signifikansi $5 \%$. Sumbangan variasi tekanan/beban pengempaan tersebut terhadap kuat tarik produk yang dihasilkan adalah 98,9\%. Hasil uji $\mathrm{t}$ sampel tunggal (one-sample $t$ test) terhadap kuat tarik menunjukkan bahwa diketahui $\mathrm{t}$ tabel : 4,303, berdasarkan hasil pengujian diketahui bahwa $\mathrm{t}$ hitung : 7,335 sehingga jelas bahwa t hitung lebih besar dari t tabel ( $\mathrm{t}$ hitung $>$ 4,303 atau $t$ hitung < -4,303), dari sini dapat diketahui bahwa semakin besar tekanan/beban pengempaan maka kuat tarik produk komposit yang dihasilkan semakin besar. Dalam variasi tekanan/beban yang terbatas tersebut diketahui bahwa tekanan/beban pengempaan optimal adalah $1400 \mathrm{~kg}$ dengan perolehan kuat tarik sebesar $26,00 \mathrm{~kg} / \mathrm{cm}^{2}$. Berangkat dari pengujian dan analisa tersebut maka tekanan/beban pengempaan optimal yang dapat ditetapkan adalah $1400 \mathrm{~kg}$.

\subsubsection{Variasi komposisi/nisbah bahan (TKKS : Plastik)}

Variasi ini memiliki arti yang sangat penting untuk dilakukan dalam rangka mencari/mengetahui komposisi/nisbah optimal yang diperlukan untuk memproduksi komposit papan dan dinding interior dengan kualitas paling optimal. Dalam Tabel 5, 6, 7 dan 8 dapat diamati bahwa perlakuan/variasi komposisi/nisbah bahan berpengaruh positif terhadap karakteristik mekanik produk yang dihasilkan. Karakteristik mekanik yang dimaksudkan adalah kuat lentur, kuat desak, kuat geser dan kuat tarik. Dalam penggunaan praktis di pasaran, kuat lentur (bending) menjadi parameter utama dan yang paling penting 
karena dapat mewakili seluruh karakteristik mekanik produk komposit sehingga parameter lainnya seperti kuat desak, geser dan tarik dapat diabaikan.

Tabel 5. Kuat Lentur berdasarkan variasi komposisi/nisbah bahan

\begin{tabular}{|c|c|c|c|c|c|}
\hline $\begin{array}{c}\text { Komposisi } \\
\text { (TKKS: } \\
\text { Plastik) }(\%)\end{array}$ & $\begin{array}{c}\text { Lebar } \\
\text { papan (a) } \\
\mathrm{cm}\end{array}$ & $\begin{array}{c}\text { Tinggi } \\
\text { papan }(\mathrm{h}) \\
\mathrm{Cm}\end{array}$ & $\begin{array}{c}\text { Panjang } \\
\text { bentang }(\mathrm{L}) \\
\mathrm{cm}\end{array}$ & $\begin{array}{c}\text { Beban } \\
\text { maksimal } \\
\text { P maks }(\mathrm{kg})\end{array}$ & $\begin{array}{c}\text { Kuat Lentur } \\
(\sigma \mathrm{t}) \\
\left(\mathrm{kg} / \mathrm{cm}^{2}\right)\end{array}$ \\
\hline $70: 30$ & 2 & 2 & 10 & 30 & 56,25 \\
\hline $60: 40$ & 2 & 2 & 10 & 52 & 97,50 \\
\hline $50: 50$ & 2 & 2 & 10 & 62 & 116,25 \\
\hline
\end{tabular}

Berdasarkan hasil analisis regresi linear terhadap variasi komposisi/nisbah bahan (TKKS : Plastik) dalam kaitannya dengan kuat lentur produk komposit yang dihasilkan seperti yang ditampilkan dalam Tabel 5 tersebut, dapat dikemukakan bahwa variasi komposisi/nisbah bahan tersebut berpengaruh positif terhadap hasil uji kuat lentur produk komposit yang dihasilkan. Diketahui harga r : 0.977 dan $\mathrm{R}^{2}$ : 0,955 dengan taraf signifikansi $5 \%$. Sumbangan variasi komposisi/nisbah bahan tersebut terhadap kuat lentur produk yang dihasilkan adalah 95,5\%. Hasil uji t sampel tunggal (one-sample $t$ test) terhadap kuat lentur menunjukkan bahwa diketahui $\mathrm{t}$ table : 4,303, berdasarkan hasil pengujian diketahui bahwa $\mathrm{t}$ hitung : 5,078 sehingga jelas bahwa $\mathrm{t}$ hitung lebih besar dari $\mathrm{t}$ tabel ( $\mathrm{t}$ hitung $>4,303$ atau $\mathrm{t}$ hitung < - 4,303), dari sini dapat diketahui bahwa semakin besar komposisi/nisbah plastik (\%) dalam komposit maka kuat lentur produk komposit yang dihasilkan semakin besar. Dalam variasi komposisi/nisbah bahan yang terbatas tersebut diketahui bahwa komposisi/nisbah bahan optimal adalah 50:50 \% dengan perolehan kuat lentur sebesar $116,25 \mathrm{~kg} / \mathrm{cm}^{2}$. Berangkat dari pengujian dan analisa tersebut maka komposisi bahan (TKKS:Plastik) optimal yang dapat ditetapkan adalah 50:50\%.

Tabel 6. Kuat Desak berdasarkan variasi komposisi/nisbah bahan

\begin{tabular}{|c|c|c|c|c|c|}
\hline $\begin{array}{c}\text { Komposisi } \\
\text { (TKKS: } \\
\text { Plastik) }(\%)\end{array}$ & $\begin{array}{c}\text { Panjang } \\
\text { penampang } \\
(\mathrm{a}) \mathrm{cm}\end{array}$ & $\begin{array}{c}\text { Lebar } \\
\text { penampang } \\
(\mathrm{b}) \mathrm{cm}\end{array}$ & $\begin{array}{c}\text { Luas } \\
\text { Penampang } \\
(\mathrm{Ag}) \mathrm{cm}^{2}\end{array}$ & $\begin{array}{c}\text { Beban } \\
\text { maksimal } \\
\text { P maks }(\mathrm{kg})\end{array}$ & $\begin{array}{c}\text { Kuat Desak } \\
(\sigma \mathrm{t}) \\
\left(\mathrm{kg} / \mathrm{cm}^{2}\right)\end{array}$ \\
\hline $70: 30$ & 2 & 2 & 4 & 111 & 27,75 \\
\hline $60: 40$ & 2 & 2 & 4 & 256 & 64,00 \\
\hline $50: 50$ & 2 & 2 & 4 & 477 & 119,25 \\
\hline
\end{tabular}

Berdasarkan hasil analisis regresi linear terhadap variasi komposisi/nisbah bahan (TKKS : Plastik) dalam kaitannya dengan kuat desak produk komposit yang dihasilkan seperti yang ditampilkan dalam Tabel 6 tersebut, dapat dikemukakan bahwa variasi komposisi/nisbah bahan tersebut berpengaruh positif terhadap hasil uji kuat desak produk komposit yang dihasilkan. Diketahui harga $\mathrm{r}: 0.993$ dan $\mathrm{R}^{2}$ : 0,986 dengan taraf signifikansi $5 \%$. Sumbangan variasi komposisi/nisbah bahan tersebut terhadap kuat desak produk yang dihasilkan adalah 98,6\%. Hasil 
uji t sampel tunggal (one-sample $t$ test) terhadap kuat desak menunjukkan bahwa diketahui $\mathrm{t}$ tabel : 4,303, berdasarkan hasil pengujian diketahui bahwa $\mathrm{t}$ hitung : 2,644 . Walaupun $t$ hitung lebih kecil dari $t$ tabel ( $t$ hitung $<4,303$ ), tetapi harga $r$ dan $\mathrm{R}^{2}$ tersebut sudah cukup kuat untuk dijadikan sebagai dasar penetapan komposisi/nisbah bahan (TKKS : Plastik) optimal, yakni 50 : 50 \% dengan perolehan kuat desak sebesar $119,25 \mathrm{~kg} / \mathrm{cm}^{2}$. Jadi dalam proses penentuan variabel optimal yang ditetapkan, langkah pertama adalah pengamatan secara visual pada hasil pengujian karakteristik mekanik, sedangkan uji dan analisa data secara statistik adalah pendukung keputusan sehingga apabila terdapat jarak (range) yang cukup jauh di antara variabel tergantungnya maka dapat langsung ditetapkan.

Tabel 7. Kuat Geser berdasarkan variasi komposisi/nisbah bahan

\begin{tabular}{|c|c|c|c|c|c|}
\hline $\begin{array}{c}\text { Komposisi } \\
\text { (TKKS: } \\
\text { Plastik) }(\%)\end{array}$ & $\begin{array}{c}\text { Panjang (a) } \\
\mathrm{cm}\end{array}$ & $\begin{array}{c}\text { Lebar }(\mathrm{b}) \\
\mathrm{cm}\end{array}$ & $\begin{array}{c}\text { Luas } \\
\text { Penampang/ } \\
\mathrm{Ag}\left(\mathrm{cm}^{2}\right)\end{array}$ & $\begin{array}{c}\text { Beban } \\
\text { maksimal } \\
\text { P maks }(\mathrm{kg})\end{array}$ & $\begin{array}{c}\text { Kuat Geser } \\
(\sigma) \\
\left(\mathrm{kg} / \mathrm{cm}^{2}\right)\end{array}$ \\
\hline $70: 30$ & 4 & 5 & 20 & 141 & 7,05 \\
\hline $60: 40$ & 4 & 5 & 20 & 289 & 14,45 \\
\hline $50: 50$ & 4 & 5 & 20 & 789 & 39,45 \\
\hline
\end{tabular}

Berdasarkan hasil analisis regresi linear terhadap variasi komposisi/nisbah bahan (TKKS : Plastik) dalam kaitannya dengan kuat geser produk komposit yang dihasilkan seperti yang ditampilkan dalam Tabel 7 tersebut, dapat dikemukakan bahwa variasi komposisi/nisbah bahan tersebut berpengaruh positif terhadap hasil uji kuat geser produk komposit yang dihasilkan. Diketahui harga $\mathrm{r}$ : 0.954 dan $\mathrm{R}^{2}$ : 0,910 dengan taraf signifikansi $5 \%$. Sumbangan variasi komposisi/nisbah bahan tersebut terhadap kuat geser produk yang dihasilkan adalah 91,0 \%. Hasil uji t sampel tunggal (one-sample $t$ test) terhadap kuat geser menunjukkan bahwa diketahui $\mathrm{t}$ tabel : 4,303, berdasarkan hasil pengujian diketahui bahwa $\mathrm{t}$ hitung : 2,073. Walaupun $t$ hitung lebih kecil dari $t$ tabel ( $t$ hitung $<4,303$ ), tetapi harga $r$ dan $\mathrm{R}^{2}$ tersebut sudah cukup kuat untuk dijadikan sebagai dasar penetapan komposisi/nisbah bahan (TKKS : Plastik) optimal, yakni 50 : $50 \%$ dengan perolehan kuat geser sebesar $39,45 \mathrm{~kg} / \mathrm{cm}^{2}$. Jadi dalam proses penentuan variabel optimal yang ditetapkan, langkah pertama adalah pengamatan secara fisik pada hasil pengujian karakteristik mekanik, sedangkan uji dan analisa data secara statistik adalah pendukung keputusan sehingga apabila terdapat jarak (range) yang cukup jauh di antara variabel tergantungnya maka dapat langsung ditetapkan.

Tabel 8. Kuat Tarik berdasarkan variasi komposisi/nisbah bahan

\begin{tabular}{|c|c|c|c|c|c|}
\hline $\begin{array}{c}\text { Komposisi } \\
\text { (TKKS: } \\
\text { Plastik) (\%) }\end{array}$ & $\begin{array}{c}\text { Panjang (a) } \\
\mathrm{cm}\end{array}$ & $\begin{array}{c}\text { Lebar }(\mathrm{b}) \\
\mathrm{cm}\end{array}$ & $\begin{array}{c}\text { Luas } \\
\text { Penampang } \\
(\mathrm{cm} 2)\end{array}$ & $\begin{array}{c}\text { Beban } \\
\text { maksimal } \\
\text { P maks }(\mathrm{kg})\end{array}$ & $\begin{array}{c}\text { Kuat } \\
\text { Tarik }(\sigma) \\
(\mathrm{kg} / \mathrm{cm} 2)\end{array}$ \\
\hline $70: 30$ & 2 & 1 & 2 & 29 & 14,50 \\
\hline $60: 40$ & 2 & 1 & 2 & 44 & 22,00 \\
\hline $50: 50$ & 2 & 1 & 2 & 51 & 25,50 \\
\hline
\end{tabular}


Berdasarkan hasil analisis regresi linear terhadap variasi komposisi/nisbah bahan (TKKS : Plastik) dalam kaitannya dengan kuat tarik produk komposit yang dihasilkan seperti yang ditampilkan dalam Tabel 8 tersebut, dapat dikemukakan bahwa variasi komposisi/nisbah bahan tersebut berpengaruh positif terhadap hasil uji kuat tarik produk komposit yang dihasilkan. Diketahui harga r : 0.979 dan $\mathrm{R}^{2}$ : 0,958 dengan taraf signifikansi $5 \%$. Sumbangan variasi komposisi/nisbah bahan tersebut terhadap kuat tarik produk yang dihasilkan adalah 95,8 \%. Hasil uji $\mathrm{t}$ sampel tunggal (one-sample $t$ test) terhadap kuat tarik menunjukkan bahwa diketahui t tabel : 4,303, berdasarkan hasil pengujian diketahui bahwa t hitung : 6,369 sehingga jelas bahwa thitung lebih besar dari $t$ tabel ( $\mathrm{t}$ hitung $>4,303$ atau $\mathrm{t}$ hitung < - 4,303), dari sini dapat diketahui bahwa semakin besar komposisi/nisbah plastik (\%) dalam komposit maka kuat tarik produk komposit yang dihasilkan semakin besar. Dalam variasi komposisi/nisbah bahan yang terbatas tersebut diketahui bahwa komposisi/nisbah bahan optimal adalah 50 : $50 \%$ dengan perolehan kuat tarik sebesar $25,50 \mathrm{~kg} / \mathrm{cm}^{2}$. Berangkat dari pengujian dan analisa tersebut maka komposisi/nisbah bahan (TKKS : Plastik) optimal yang dapat ditetapkan adalah $50: 50 \%$.

\subsubsection{Variasi ukuran TKKS (mesh)}

Variasi ini memiliki arti yang sangat penting untuk dilakukan dalam rangka mencari/mengetahui ukuran TKKS optimal yang diperlukan untuk memproduksi komposit papan dan dinding interior dengan kualitas paling optimal. Dalam Tabel 9, 10, 11 dan 12 dapat diamati bahwa perlakuan/variasi ukuran TKKS berpengaruh terhadap karakteristik mekanik produk yang dihasilkan.

Tabel 9. Kuat Lentur berdasarkan variasi ukuran TKKS

\begin{tabular}{|c|c|c|c|c|c|}
\hline $\begin{array}{c}\text { Ukuran } \\
\text { TKKS } \\
(\mathrm{mesh})\end{array}$ & $\begin{array}{c}\text { Lebar } \\
\text { papan (a) } \\
\mathrm{cm}\end{array}$ & $\begin{array}{c}\text { Tinggi } \\
\text { papan }(\mathrm{h}) \\
\mathrm{Cm}\end{array}$ & $\begin{array}{c}\text { Panjang } \\
\text { bentang }(\mathrm{L}) \\
\mathrm{cm}\end{array}$ & $\begin{array}{c}\text { Beban } \\
\text { maksimal } \\
\text { P maks }(\mathrm{kg})\end{array}$ & $\begin{array}{c}\text { Kuat Lentur } \\
(\sigma \mathrm{lt}) \\
\left(\mathrm{kg} / \mathrm{cm}^{2}\right)\end{array}$ \\
\hline 30 & 2 & 2 & 10 & 50 & 93,75 \\
\hline 50 & 2 & 2 & 10 & 70 & 118,13 \\
\hline 70 & 2 & 2 & 10 & 63 & 108,75 \\
\hline
\end{tabular}

Tampak jelas dalam Tabel 9 tersebut bahwa kuat lentur produk komposit papan dan dinding interior yang dihasilkan meningkat seiring dengan semakin kecilnya ukuran TKKS sampai batas tertentu. Dalam Tabel 9 tersebut ditampilkan variasi ukuran TKKS secara terbatas dan ternyata ukuran TKKS optimal yang dapat direkomendasikan adalah 50 mesh dengan perolehan kuat lentur sebesar $118,13 \mathrm{~kg} / \mathrm{cm}^{2}$. Penetapan tersebut didasari oleh hasil uji t sampel tunggal (onesampel t test) terhadap kuat lentur produk komposit yang dihasilkan dimana t tabel diketahui : 4,303 dan t hitung diketahui : 15,053. Jadi jelas bahwa t hitung telah memenuhi persyaratan ( $\mathrm{t}$ hitung $>4,303$ atau $\mathrm{t}$ hitung $<-4,303$ ). Dalam menganalisa hasil pengujian kuat lentur produk komposit papan dan dinding 
inteior yang dihasilkan kaitannya dengan variasi ukuran TKKS tidak dapat menggunakan analisis regresi linear sebagai alat analisa. Hal itu disebabkan kuat lentur yang dihasilkan tidak berkorelasi secara linear terbukti dengan harga $\mathrm{r}$ : 0,610 dan harga $\mathrm{R}^{2}: 0,372$.

Tabel 10. Kuat Desak berdasarkan variasi ukuran TKKS

\begin{tabular}{|c|c|c|c|c|c|}
\hline $\begin{array}{c}\text { Ukuran } \\
\text { TKKS } \\
(\mathrm{mesh})\end{array}$ & $\begin{array}{c}\text { Panjang } \\
\text { penampang } \\
(\mathrm{a}) \mathrm{cm}\end{array}$ & $\begin{array}{c}\text { Lebar } \\
\text { penampang } \\
(\mathrm{b}) \mathrm{cm}\end{array}$ & $\begin{array}{c}\text { Luas } \\
\text { Penampang } \\
(\mathrm{Ag}) \mathrm{cm}^{2}\end{array}$ & $\begin{array}{c}\text { Beban } \\
\text { maksimal } \\
\text { P maks }(\mathrm{kg})\end{array}$ & $\begin{array}{c}\text { Kuat Desak } \\
(\sigma \mathrm{t}) \\
\left(\mathrm{kg} / \mathrm{cm}^{2}\right)\end{array}$ \\
\hline 30 & 2 & 2 & 4 & 107 & 26,75 \\
\hline 50 & 2 & 2 & 4 & 658 & 164,50 \\
\hline 70 & 2 & 2 & 4 & 508 & 127,00 \\
\hline
\end{tabular}

Tampak jelas dalam Tabel 10 tersebut bahwa kuat desak produk komposit papan dan dinding interior yang dihasilkan meningkat seiring dengan semakin kecilnya ukuran TKKS sampai batas tertentu. Dalam Tabel 10 tersebut ditampilkan variasi ukuran TKKS secara terbatas dan ternyata ukuran TKKS optimal yang dapat direkomendasikan adalah 50 mesh dengan perolehan kuat desak sebesar $164,50 \mathrm{~kg} / \mathrm{cm}^{2}$. Walaupun hasil uji $\mathrm{t}$ sampel tunggal (one-sampel $t$ test) menghasilkan $t$ hitung : 2,580 yang jelas lebih kecil dari $t$ tabel : 4,303, tetapi data yang ditampilkan dalam Tabel 10 tersebut sudah cukup jelas untuk dijadikan sebagai bahan pertimbangan untuk menetapkan variasi ukuran yang optimal yakni $50 \%$. Jarak (range) yang cukup jauh tersebut secara signifikan berpengaruh terhadap proses pengujian dan analisa data sehingga uji t tersebut menjadi tidak efektif dan begitu pula analisis regresi terhadap data tersebut, juga tidak efektif karena secara visual tampak bahwa tidak terdapat korelasi yang signifikan ; $\mathrm{r}$ : 0,704 dan $\mathrm{R}^{2}: 0,495$.

Tabel 11. Kuat Geser berdasarkan variasi ukuran TKKS

\begin{tabular}{|c|c|c|c|c|c|}
\hline $\begin{array}{c}\text { Ukuran } \\
\text { TKKS } \\
(\mathrm{mesh})\end{array}$ & $\begin{array}{c}\text { Panjang (a) } \\
\mathrm{cm}\end{array}$ & $\begin{array}{c}\text { Lebar (b) } \\
\mathrm{cm}\end{array}$ & $\begin{array}{c}\text { Luas } \\
\text { Penampang/ } \\
\mathrm{Ag}\left(\mathrm{cm}^{2}\right)\end{array}$ & $\begin{array}{c}\text { Beban } \\
\text { maksimal } \\
\text { P maks }(\mathrm{kg})\end{array}$ & $\begin{array}{c}\text { Kuat Geser } \\
(\sigma) \\
\left(\mathrm{kg} / \mathrm{cm}^{2}\right)\end{array}$ \\
\hline 30 & 4 & 5 & 20 & 135 & 6,75 \\
\hline 50 & 4 & 5 & 20 & 789 & 39,45 \\
\hline 70 & 4 & 5 & 20 & 615 & 30,75 \\
\hline
\end{tabular}

Tampak jelas dalam Tabel 11 tersebut bahwa kuat geser produk komposit papan dan dinding interior yang dihasilkan meningkat seiring dengan semakin kecilnya ukuran TKKS sampai batas tertentu, seperti halnya data yang ditampilkan dalam Tabel 10. Dalam Tabel 11 tersebut ditampilkan variasi ukuran TKKS secara terbatas dan ternyata ukuran TKKS optimal yang dapat direkomendasikan adalah 50 mesh dengan perolehan kuat geser sebesar 39,45 $\mathrm{kg} / \mathrm{cm}^{2}$. Walaupun hasil uji $\mathrm{t}$ sampel tunggal (one-sampel $t$ test) menghasilkan $\mathrm{t}$ hitung : 2,623 yang tentu lebih kecil dari $\mathrm{t}$ tabel : 4,303, tetapi data yang 
ditampilkan dalam Tabel 11 tersebut sudah cukup jelas untuk dijadikan sebagai bahan pertimbangan untuk menetapkan variasi ukuran yang optimal yakni $50 \%$. Jarak (range) yang cukup jauh tersebut secara signifikan berpengaruh terhadap proses pengujian dan analisa data sehingga uji t tersebut menjadi tidak efektif dan begitu pula analisis regresi terhadap data tersebut, juga tidak efektif karena secara visual tampak bahwa tidak terdapat korelasi yang signifikan ; harga $r$ : 0,709 sedangkan $\mathrm{R}^{2}: 0,502$.

Tabel 12. Kuat Tarik berdasarkan variasi ukuran TKKS

\begin{tabular}{|c|c|c|c|c|c|}
\hline $\begin{array}{c}\text { Ukuran } \\
\text { TKKS } \\
(\mathrm{mesh})\end{array}$ & $\begin{array}{c}\text { Panjang (a) } \\
\mathrm{cm}\end{array}$ & $\begin{array}{c}\text { Lebar }(\mathrm{b}) \\
\mathrm{cm}\end{array}$ & $\begin{array}{c}\text { Luas } \\
\text { Penampang } \\
(\mathrm{cm} 2)\end{array}$ & $\begin{array}{c}\text { Beban } \\
\text { maksimal } \\
\text { P maks }(\mathrm{kg})\end{array}$ & $\begin{array}{c}\text { Kuat } \\
\text { Tarik }(\sigma) \\
(\mathrm{kg} / \mathrm{cm} 2)\end{array}$ \\
\hline 30 & 2 & 1 & 2 & 32 & 16,00 \\
\hline 50 & 2 & 1 & 2 & 51 & 25,50 \\
\hline 70 & 2 & 1 & 2 & 29 & 14,50 \\
\hline
\end{tabular}

Tampak jelas dalam Tabel 12 tersebut bahwa kuat tarik produk komposit papan dan dinding interior yang dihasilkan meningkat seiring dengan semakin kecilnya ukuran TKKS sampai batas tertentu. Dalam Tabel 12 tersebut ditampilkan variasi ukuran TKKS secara terbatas dan ternyata ukuran TKKS optimal yang dapat direkomendasikan adalah 50 mesh dengan perolehan kuat tarik sebesar $25,50 \mathrm{~kg} / \mathrm{cm}^{2}$. Penetapan tersebut didasari oleh hasil uji t sampel tunggal (onesampel $t$ test) terhadap kuat tarik produk komposit yang dihasilkan dimana $t$ tabel diketahui : 4,303 dan $\mathrm{t}$ hitung diketahui : 5,420. Jadi jelas bahwa $\mathrm{t}$ hitung telah memenuhi persyaratan ( $\mathrm{t}$ hitung $>4,303$ atau $\mathrm{t}$ hitung $<-4,303$ ). Dalam menganalisa hasil pengujian kuat tarik produk komposit papan dan dinding inteior yang dihasilkan kaitannya dengan variasi ukuran TKKS tidak dapat menggunakan analisis regresi linear sebagai alat analisa. Hal itu disebabkan secara visual tampak bahwa tidak terdapat korelasi yang signifikan kaitannya dengan variasi ukuran TKKS secara berurutan terhadap kuat tarik yang dihasilkan ; $\mathrm{r}$ : 0,126 dan $\mathrm{R}^{2}: 0,016$.

\section{SIMPULAN}

Penelitian ini merupakan penelitian dasar yang berusaha untuk mengetahui karakteristik mekanik produk fiberboards yang diproduksi dari komposit sampah plastik (thermoplastic) dan limbah tandan kosong kelapa sawit (TKKS) yang sangat melimpah dan telah menjadi persoalan serius bangsa Indonesia. Berdasarkan hasil penelitian ini dapat disimpulkan bahwa sampah plastik (thermoplastic) dan limbah tandan kosong kelapa sawit (TKKS) memiliki potensi yang sangat besar dimanfaatkan secara optimal sebagai bahan baku produksi fiberboards. Produk fiberboards yang dihasilkan memiliki karakteristik mekanik yang sangat memuaskan baik kuat lentur, kuat desak, kuat geser maupun kuat tarik. Penelitian ini masih membutuhkan penelitian tingkat lanjut dalam kaitannya dengan 
optimasi proses untuk menghasilkan produk fiberboards dengan tingkat replikasi dan reliabilitas yang baik sesuai dengan fungsi dan aplikasinya.

\section{DAFTAR PUSTAKA}

[1] Wahyono, et al., (2003) Pembuatan Kompos dari Tandan Kosong Kelapa Sawit. Jurnal Saint dan Teknologi (IPTEK). BPPT. Vol. 1, Hal. 375-386.

[2] Ridlo, R., (2001) Pembakaran Limbah Tandan Kosong kelapa Sawit dan Batubara Menggunakan Circulating Fluidized Bed (CFB) di Kalimantan Timur. Jurnal Saint dan Teknologi Indonesia. BPPT. Vol. 3, No. 5, Hal. 17-234.

[3] Anonim, (2003) Kiat Memanfaatkan Sampah di Perkotaan, Kompas 29 Juli 2003,

[4] http://www.kompas.com/kompas-cetak/0307/29/inspirasi/458014.htm

[5] Feris Firdaus dan Fajriyanto, (2006) Komposit Sampah Plastik-Limbah Tandan Kosong Kelapa Sawit Sebagai Material Utama Untuk Produksi Fiberboards. Proceeding Seminar Nasional Kimia III 2006, ISBN : 979-96595-2-3, Hal. 112121. Penelitian yang dibiayai dalam program Riset Unggulan Terpadu (RUT XII) 2005-2006 oleh Menristek RI.

[6] Setyawati,D., (2003) Sifat Fisis dan Mekanis Komposit Serbuk kayu Plastik Polipropilena Daur Ulang. [Thesis]. Program Pascasarjana Institut Pertanian Bogor. Bogor (tidak dipublikasikan).

[7] Sulaeman, R., (2003) Deteriorasi Komposit Serbuk kayu Plastik Polipropilena Daur Ulang Oleh Cuaca Dan Rayap. [Thesis] Program Pascasarjana Institut Pertanian Bogor. Bogor (tidak dipublikasikan).

[8] Febrianto F, Y.S. Hadi, dan M. Karina., (2001) Teknologi produksi recycle komposit bemutu tinggi dari limbah kayu dan plastik: Sifat-sifat papan partikel pada berbagai nisbah campuran serbuk dan plastik polipropilene daur ulang dan ukuran serbuk. Laporan Akhir Hibah Bersaing IX/1. direktorat Jenderal Pendidikan Tinggi, Departemen Pendidikan Nasional.

[9] Febrianto F., (1999) Preparation And Properties Enhancement Of Moldable Wood - Biodegradable Polymer Composites. [Disertasi]. Kyoto: Kyoto University, Doctoral Dissertation.Division of Forestry and Bio-material Science. Faculty of Agriculture. Tidak dipublikasikan.

[10] Oksman K, Clemons C., (1997) Effect of elastomers and coupling agent on impact performance of wood flour-filled polypropilene. Di dalam: Fourth International Conference on Woodfiber-Plastic Composites. Madison, 12 -14 Mei 1997. Wisconsin: Forest Product Sociaty. hlm 144-155.

[11] Strak NM. dan Berger MJ., (1997) Effect of particle size on properties of woodflour reinforced polypropylene composites. Di dalam: Fourth International Conference on Woodfiber-Plastic Composites. Madison, 12 -14 Mei 1997. Wisconsin: Forest Product Sociaty. hlm 134-143.

[12] Prayitno, T.A., (1995) Pengujian Sifat Fisika dan Mekanika Menurut ISO, Universitas Gadjah Mada, Yogyakarta.

[13] Han GS., (1990) Preparation and Physical Properties Of Moldable Wood Plastic Composites. [Disertasi]. Kyoto: Kyoto University. Departement Of Wood Science and Technology, Faculty of Agriculture. 